\title{
Nutrient uptake by leaves and roots of the seagrass Thalassia hemprichii in the Spermonde Archipelago, Indonesia
}

\author{
Johan Stapel*, Thelma L. Aarts, Bert H. M. van Duynhoven, Jacqueline D. de Groot, \\ Paul H. W. van den Hoogen, Marten A. Hemminga
}

Netherlands Institute of Ecology, Centre for Estuarine and Coastal Ecology, Vierstraat 28, 4401 EA Yerseke, The Netherlands

\begin{abstract}
The kinetics of ammonium and phosphate uptake by leaves and roots of the tropical seagrass Thalassia hemprichii were investigated in laboratory experiments. Uptake in leaves of plants from 3 different locations, covering the range from coastal to oceanic conditions in the region of investigation (Spermonde Archipelago, South Sulawesi, Indonesia), was compared. The leaves from all plant samples showed a clear capacity for both ammonum and phosphate uptake. This uptake could be described by Michaelis-Menten kinetics. $V_{\max }$ ranged between 32 and $37 \mathrm{mmol} \mathrm{g}^{-1}$ leaf dry weight $\mathrm{h}^{-1}$ for ammonium and between 2.2 and $3.2 \mu \mathrm{mol} \mathrm{g}^{-1}$ leaf dry weight $\mathrm{h}^{-1}$ for phosphate. $K_{\mathrm{m}}$ ranged between 21. and $60 \mu \mathrm{M}$ for ammonium and between 7.7 and $15 \mu \mathrm{M}$ for phosphate. There was no significant site difference in uptake characteristics $\left(v_{\max }\right.$ and $\left.K_{\mathrm{m}}\right)$ of ammonium and phosphate. Uptake of ammonium and phosphate by roots was investigated with plants from the intermediate location, Barang Lompo, using an approach which allowed only calculation of uptake rates at natural pore water concentrations. Uptake rates were 22 and $1.0 \mu \mathrm{mol} \mathrm{g}^{-1}$ root dry weight $\mathrm{h}^{-1}$ for ammonium and phosphate, respectively. Calculations suggest that at all 3 locations uptake of ammonium and phosphate by roots was probably limited by the diffusion of nutrients in the sediment rather than by their uptake capacity. Evidence was found that the availability of nutrients in the root zone relative to the leaf zone affects the uptake affinity of the leaves. The role of roots versus leaves in supplying plant nutrients is discussed. We concluded that even in the tropics, where water column nutrient concentrations are often very low, leaves clearly have a significant ability for ammonium or phosphate uptake and that in some situations nutrient uptake by the leaves may even be essential in meeting plant nutrient demands.
\end{abstract}

KEY WORDS: Ammonium - Phosphate - Nutrient uptake kinetics Leaves - Roots - Seagrass - Thalassia hemprichii Indonesia

\section{INTRODUCTION}

Seagrass beds are widespread in shallow coastal waters around the world, except for the polar regions (Den Hartog 1970). They rank among the most productive submerged aquatic ecosystems (Zieman \& Wetzel 1980, Larkum \& West 1983, Hillman et al. 1989). To maintain this production, an adequate nutrient availability is essential. However, seagrass beds are open systems and various processes common to the dynamic

\footnotetext{
•E-mail: stapel@cemo.n100.knaw.nl
}

conditions of their habitat may lead to nutrient loss. The persistence of seagrass meadows depends on mechanisms that replenish these lost nutrients. Among others, nutrient uptake by leaves is considered as a process which contributes to compensation of nutrient losses (see review by Hemminga et al. 1991).

Seagrasses are able to take up nutrients from both the interstitial water of the sediment and the ambient water column. Leaves have a much higher turnover than roots and rhizomes, and contain more nitrogen and phosphorus relative to carbon (Erftemeijer et al. 1993). Hence, it can be assumed that most of the nutrients derived from mineralized biomass originate 
from the leaves. Consequently, the major portion of the nutrients resulting from decomposition of dead seagrass tissue may be released in the water column, although burial of deposited seagrass leaves and leaf fragments in the sediment (by bioturbation) could to some extent restrict this amount. Traditionally, it is assumed that nutrient uptake by roots of aquatic weeds dominates over uptake by leaves (i.e. Carignan \& Kalff 1980). Several studies, however, indicate that nitrogen uptake by leaves can contribute considerably to the total nitrogen uptake of seagrasses (30 to $90 \%$; Iizumi \& Hattori 1982, Short \& McRoy 1984, Hemminga et al. 1991, 1994, Pedersen \& Borum 1992, 1993). Tropical seagrass beds are characterized by high productivity at low ambient nutrient concentrations in the water column and relatively high nutrient concentrations in the pore water (Brouns \& Heijs 1986, Lindeboom \& Sandee 1989, Nienhuis et al. 1989, Erftemeijer et al. 1993). We are not aware of any published data concerning the uptake capabilities of leaves and roots of tropical seagrasses. One would expect that these seagrasses rely mainly on the root system for nutrient uptake considering the very low nutrient concentrations in the water column compared

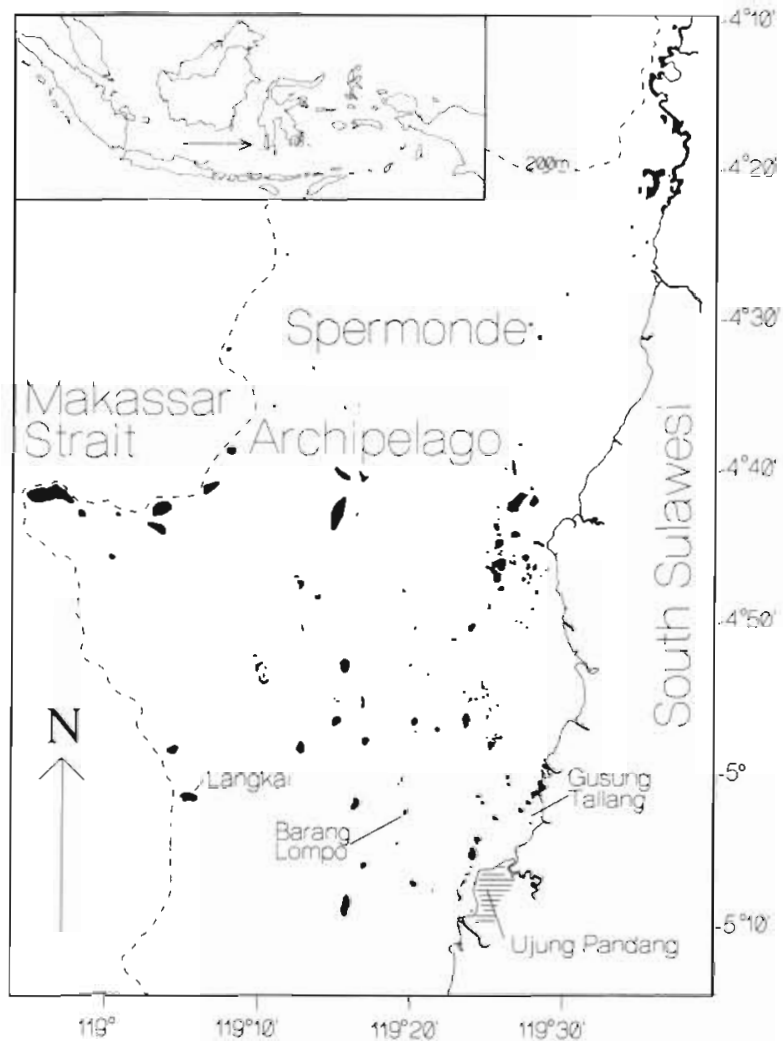

Fig. 1. Study area, showing islands and submerged reefs of the Spermonde Archipelago along the west coast of South Sulawesi. Dashed line: shelf edge $(200 \mathrm{~m})$. Inset: Indonesian Archipelago to those in the pore water. Viewed from this perspective, uptake capabilities of leaves of tropical seagrasses may not be strongly developed. On the other hand, such a capability could be important for the reduction of system nutrient losses: nutrients diffusing from the sediment or released from leaves decomposing in the water column could be recaptured (Hemminga et al. 1991, Pedersen \& Borum 1993).

In this study, the kinetics of ammonium and phosphate uptake by leaves and roots of the tropical seagrass Thalassia hemprichii (Ehrenb.) Aschers. were investigated. Plants from 3 locations, which are representative of coastal to oceanic field conditions in the research area, were compared. Uptake of ammonium was studied as a preference of ammonium over nitrate uptake in seagrasses, as indicated by data of Doddema \& Howari (1983), Short \& McRoy (1984) and Hemminga et al. (1994), even at a relatively high nitrate:ammonium concentration ratio. Data of Erftemeijer (1994) indicate that at the 3 sites relevant to this study, ammonium is the dominant form of inorganic nitrogen in both pore water (ca $20 \times$ higher ammonium concentration) and the water column ( 2 to $4 \times$ higher ammonium concentration).

\section{MATERIALS AND METHODS}

Study area. Thalassia hemprichii (Ehrenb.) Aschers was collected from 3 locations in the Spermonde Archipelago along the west coast of South Sulawesi, Indonesia (Fig. 1). This archipelago consists of a large group of coral islands and submerged reefs distributed on the Spermonde continental shelf (De Klerk 1982). The reef flats of most of the islands and the shallow areas along the coast are covered with seagrass beds (Erftemeijer et al. 1993). The 3 selected locations represent contrasting field sites. The intertidal mudflat of Gusung Tallang is located approximately $5 \mathrm{~km}$ north of Ujung Pandang. It is characterized by riverine inputs from the nearby mouth of the Telo creek. The sediment consists of sandy terrigenous mud and contains about $11 \% \mathrm{CaCO}_{3}$. It is protected from waves and currents by long, narrow sandbars perpendicular to the coast. Well developed, mixed ( 7 species) seagrass beds occur between these sandbars. The other field sites, Barang Lompo and Langkai, are both coral islands surrounded by large intertidal reef flats with extensive multispecies ( 6 to 7 ) seagrass vegetations. The reef flats consist of relatively coarse carbonate sand and coral rubble (93 to $100 \% \mathrm{CaCO}_{3}$ Erftemeijer 1993). Barang Lompo is located approximately $14 \mathrm{~km}$ off the coast, whereas Langkai is situated at the shelf edge, $40 \mathrm{~km}$ off the coast. The latter site is characterized by clear ocean water, relatively strong unidirectional currents 
and a relatively strong wash of the waves. The reef flat of Barang Lompo lacks conspicuous river or oceanic influences. Only during the peak of the wet season (January-February) may terrestrial inputs reach this island. The water above the seagrass beds of Gusung Tallang is relatively turbid compared to that of Barang Lompo and Langkai, as is demonstrated by a much lower Secchi depth at Gusung Tallang (1.2 m) than at the other sites ( 18 to $20 \mathrm{~m}$ ). There is also a difference in epiphyton loads on the seagrasses. At Gusung Tallang, other species were found on the leaves, with a higher total biomass (Erftemeijer 1994, Sterrenburg et al. 1995). However, seagrasses occur in approximately the same densities at all 3 locations (ca 1000 shoots $\mathrm{m}^{-2}$ ) and are of comparable size.

Nutrient parameters. Surface water was sampled in opaque bottles and transported on ice (4 replicate samples at each sampling date). After filtration (Whatman $\mathrm{GF} / \mathrm{C}$ ), the dissolved inorganic ammonium and phosphate contents of the samples were determined colorimetrically according to Strickland \& Parsons (1972) using a Nanocolor 100 D-MN filter photometer.

Sediment samples were taken with small hand corers (diameter $6 \mathrm{~cm}$ ) to a depth of 10 to $14 \mathrm{~cm}$. This depth covers the total root zone of Thalassia hemprichii: the roots of this species normally do not extend deeper than 8 to $10 \mathrm{~cm}$. Each core was separated into $2 \mathrm{~cm}$ sections. The corresponding sections of 6 successive cores were combined and treated as 1 sample. Two series of 6 cores were collected at each sampling occasion, representing 2 replicates. These samples were transported on ice in sealed plastic bags for further treatment in the laboratory. Within $6 \mathrm{~h}$ after sampling, plant parts, shells and large stones were removed and pore water was subsequently extracted by filtration over membrane filters (Schleicher \& Schüll; $0.45 \mu \mathrm{m}$ ) under maximum $1 \mathrm{~atm}$ effective pressure using nitrogen gas (Kelderman 1985). Subsequently, dissolved inorganic ammonium and phosphate in the pore water were analyzed.

Experimental methods. General: Clumps of Thalassia hemprichii were dug out at Gusung Tallang, Barang Lompo and Langkai. These clumps were separated into units (hereafter referred to as plants) composed of a shoot, a piece of rhizome (approximately 2 to $3 \mathrm{~cm}$ ) and intact roots. After transport to the laboratory, epibiota were gently wiped from the leaves and dead and senescent tissue was removed. In the case of experiments on root uptake, the roots were carefully rinsed with seawater to remove as much adherent sediment as possible. Plants of approximately the same size (comparable leaf and root dimensions) were selected and kept in natural seawater at ambient temperatures until incubation the next day. At the start of an experiment, plants were placed in cylindrical plexiglass 2 -compartment incuba- tion vessels ( 3 plants per vessel). In these incubation vessels the leaves were separated from the roots/ rhizome by a perforated synthetic disk. Leakage between the 2 compartments was prevented by application of silicone and a low-melting-point wax. The upper (leaf) and the lower (root/rhizome) compartments had volumes of 400 and $200 \mathrm{ml}$, respectively (diameter of the incubation cylinder: $6 \mathrm{~cm}$; length of the compartments: 20 and $7 \mathrm{~cm}$, respectively). The compartments were filled with filtered seawater (Whatman glassfiber GF/C) enriched with various levels of ammonium $\left(\mathrm{NH}_{4} \mathrm{Cl}\right)$ and phosphate $\left(\mathrm{KH}_{2} \mathrm{PO}_{4}\right)$. Initial concentrations were calculated. Caffeic acid $\left(1 \mathrm{mg} \mathrm{l}^{-1}\right)$ was added to prevent bacterial growth (Hemminga et al. 1994). Prior to incubation, the medium in the root compartment was flushed with nitrogen gas to create a low oxygen environment. During the experiment, the root compartment was screened from light and its medium was mixed by magnetic stirring, whereas the medium in the leaf compartment was flushed gently with air bubbles. The incubation vessels were kept at a constant temperature $\left(28^{\circ} \mathrm{C}\right)$ in a thermostated waterbath. Six strip lights (Philips TLD 18W/33) provided approximately $200 \mu \mathrm{E} \mathrm{m}^{-2} \mathrm{~s}^{-1}$ (PAR) at plant level. The leaf compartments were open at the top; but, in order to allow manipulation of the root compartments, the root compartments were provided with 2 injection ports through which exchange was possible. Medium for the root compartment was sampled by slow injection of seawater medium into the lower injection port, which pushed medium out through the upper injection port. The outflowing medium was collected in a test tube after the first ml was discarded. During sampling the medium. was not stirred.

At the end of an incubation, $10 \mathrm{ml}$ phenol red dye $\left(0.1 \mathrm{mg} \mathrm{ml}^{-1}\right)$ was added to the leaf compartment to check for leakage. If, after at least $1 \mathrm{~h}$, the dye could be shown colorimetrically $(540 \mathrm{~nm})$ in the root compartment, the results from the incubation vessel in question were omitted. After the incubations, leaves, roots and rhizomes were dried at $80^{\circ} \mathrm{C}$ for $24 \mathrm{~h}$ and weighed. Nutrient concentrations in the incubation mediums and in the collected samples were measured colorimetrically as described above.

Uptake kinetics of leaves: According to Short \& McRoy (1984), the first 10 to 20 min of nutrient uptake experiments are characterized by an apparent high. initial uptake. This is ascribed to the combined effects of the adsorption of ions onto the plant surface and the absorption of ions into the plant tissue. After this first phase, nutrients disappear from the medium by absorption only. In the present study, the nutrient uptake kinetics of leaves were examined in plants for which the adsorption complex was assumed to be saturated. To achieve saturation, plants and incubation vessels 
used in the uptake experiments were pre-incubated at $30 \mu \mathrm{M}$ ammonium and $5 \mu \mathrm{M}$ phosphate for $1 \mathrm{~h}$.

Ammonium uptake experiments with leaves were carried out from April to June 1993. The experiments started with ammonium concentrations in the leaf compartment of $4,30,100$ or $150 \mu \mathrm{M}$ (experiments with plants from Barang Lompo), 75 or $150 \mu \mathrm{M}$ (plants from Gusung Tallang) and 30,100 or $150 \mu \mathrm{M}$ (plants from Langkai). The initial ammonium concentration in the root compartment was always $30 \mu \mathrm{M}$. Phosphate uptake experiments with leaves were carried out from January to March 1994. The experiments started with initial phosphate concentrations of $5,10,20,50$ or $70 \mu \mathrm{M}$ (experiments with plants from Barang Lompo), $5,10,20$ or $50 \mu \mathrm{M}$ (plants from Gusung Tallang) and $5,10,20$ or $50 \mu \mathrm{M}$ (plants from Langkai). The initial root compartment phosphate concentration in these experiments was $10 \mu \mathrm{M}$. Blank chambers without plants but containing the initial media were incubated simultaneously. The media of the leaf compartments were sampled every hour (ammonium) or every $2 \mathrm{~h}$ (phosphate) until the nutrients were exhausted, with a maximal incubation time of approximately $10 \mathrm{~h}$. The change in concentration (dS) during a time interval $(\mathrm{d} t)$, corrected for the changed volume after each sampling occasion, was used to calculate the uptake rate $(V)$ at the average concentration over the $\mathrm{d} t$ in question. The effect of nutrient concentration (S) on nutrient uptake rate was modelled by the MichaelisMenten equation $\left(V=V_{\max } \times S \times\left(S+K_{\mathrm{m}}\right)^{-1}\right)$, where $V_{\max }$ represents the maximum uptake rate and $K_{\mathrm{m}}$ the concentration where $V=0.5 v_{\max }$. This model is commonly used to describe nutrient uptake kinetics of higher (aquatic) plants (Iizumi \& Hattori 1982, Thursby \& Harlin 1982, 1984, Jungk 1991, Nissen 1991, Berges et al. 1994). The model, as it is presented here, does not take into account possible limitation caused by diffusion of nutrients through the unstirred layer (the boundary layer) around the leaves (Smith \& Walker 1980). In this investigation, we studied uptake in well-mixed conditions. We therefore assumed that the importance of unstirred layers for nutrient uptake in our experiments was limited. The curves describing the relation between phosphate concentration and uptake rate had a positive intercept on the $x$-axis. Therefore a term representing the phosphate concentration at which net uptake is zero $\left(S_{\min }\right)$ was added to the Michaelis-Menten equation: $V=V_{\max } \times\left(S-S_{\min }\right)$ $\times\left(S-S_{\min }+K_{\mathrm{m}}\right)^{-1}$ (Jungk 1991), giving the model a much better fit $\left(R^{2}\right)$. SYSTAT non-linear least square regression was used to fit the data to the uptake models and to calculate kinetic and statistical parameters.

Uptake kinetics of roots: We did not succeed in obtaining data on root uptake dynamics with the approach described for leaf uptake, as leakage between the 2 compartments after successive sampling of the root compartment could not be adequately avoided. Therefore a different experimental approach was followed, using incubation vessels of which the root compartment was sampled only once. These root uptake studies were executed in the period August to November 1992, with plants collected at Barang Lompo only. In each experiment, incubations were carried out in 9 vessels simultaneously. The plants used in this experiment were not pre-incubated. For the study of ammonium uptake, an initial ammonium concentration of $54 \mu \mathrm{M}$ was used in the root compartment. This level is a good representation of the inorganic ammonium concentration found in the pore water surrounding the roots in our study area (Erftemeijer \& Middelburg 1993, Erftemeijer 1994, this study). The initial ammonium concentration of the medium in the leaf compartment was $18 \mu \mathrm{M}$. For the study of phosphate uptake, the initial phosphate concentration in the root compartment was $6.5 \mu \mathrm{M}$ (similar to the natural pore water phosphate concentration). The initial phosphate concentration in the leaf compartment was $6.5 \mu \mathrm{M}$ as well. After $t=10,15,20,30,45,75,120,210$ and $300 \mathrm{~min}$, respectively, the medium of the root compartment of one of the incubation vessels was sampled in order to determine the remaining ammonium or phosphate concentrations. The incubations were repeated in 3 separate experiments; similar time samples were treated as replicates. The time series approach for root uptake (accumulation vs time) does not allow modelling of the data to the Michaelis-Menten equation (i.e. uptake rate vs substrate concentration). The uptake rates ( $\mu \mathrm{mol} \mathrm{N}$ or $\mathrm{P}^{-1}$ root dry weight $\mathrm{h}^{-1}$ ) were calculated by differentiation of the mathematical relationship of accumulation versus time.

\section{RESULTS}

\section{Nutrient parameters}

The water column concentrations at Barang Lompo and Gusung Tallang shown in Table $1 \mathrm{~A}$ are based on frequent sampling of these locations during the period August 1990 until August 1993 (Erftemeijer 1994, Erftemeijer \& Herman 1994, this study). Only figures from the same months as the ones during which the uptake experiments were carried out were used. The concentrations reported for Langkai are based on a limited set of samples obtained on 2 (ammonium) and 3 (phosphate) occasions. At all locations, the inorganic water column concentrations of ammonium and phosphate were low $\left(\mathrm{NH}_{4}{ }^{+}: 0.2\right.$ to $5.4 \mu \mathrm{M}$ and $\mathrm{PO}_{4}{ }^{3-}: \leq 1.2 \mu \mathrm{M}$; Table $1 \mathrm{~A}$ ). The range of ammonium and phosphate 
Table 1. Nutrients in the water column and pore water at Gusung Tallang, Barang Lompo and Langkai. (A) Concentration ranges and averages of inorganic ammonium and phosphate $(\mu \mathrm{M})$ in the water column. (B) Average concentrations of inorganic ammonium and phosphate $(\mu \mathrm{M})$ over the total presented depth range (Fig. 2). (C) Concentration ratios (average water column:average pore water) bdl: below detection limits. Averages $\pm \mathrm{SD} ; \mathrm{n}$ : number of observations

\begin{tabular}{|c|c|c|c|c|}
\hline & & $\begin{array}{l}\text { Gusung Tallang } \\
\text { (coast) }\end{array}$ & $\begin{array}{l}\text { Barang Lompo } \\
\text { (intermediate) }\end{array}$ & $\begin{array}{c}\text { Langkai } \\
\text { (shelf edge) }\end{array}$ \\
\hline \multicolumn{5}{|c|}{ A. Water column } \\
\hline Ammonium & $\begin{array}{l}\text { average } \\
\text { range }\end{array}$ & $\begin{array}{c}2.6 \pm 1.9(n=16) \\
0.6-5.4\end{array}$ & $\begin{array}{c}2.2 \pm 1.5(n=91) \\
0.8-5.3\end{array}$ & $\begin{array}{c}1.0 \pm 0.50(n=6) \\
0.2-1.6\end{array}$ \\
\hline Phosphate & $\begin{array}{l}\text { average } \\
\text { range }\end{array}$ & $\begin{array}{c}0.6 \pm 0.30(n=16) \\
0.3-1.1\end{array}$ & $\begin{array}{c}0.3 \pm 0.21(n=91) \\
b d l-1.2\end{array}$ & $\begin{array}{c}0.1 \pm 0.04(n=18) \\
0.1-0.2\end{array}$ \\
\hline \multicolumn{5}{|l|}{ B. Pore water } \\
\hline \multicolumn{2}{|l|}{ Ammonium } & $136 \pm 7(\mathrm{n}=2)$ & $60 \pm 10(n=2)$ & $106 \pm 11(n=2)$ \\
\hline \multicolumn{2}{|l|}{ Phosphate } & $0.92 \pm 0.49(n=16)$ & $5.5 \pm 2.5(\mathrm{n}=31)$ & $5.4^{\mathrm{a}}$ \\
\hline \multicolumn{5}{|c|}{ C. Average water column:average pore water ratio } \\
\hline \multicolumn{2}{|c|}{ Ammonium } & 0.019 & 0.039 & 0.0094 \\
\hline \multicolumn{2}{|l|}{ Phosphate } & 0.64 & 0.051 & 0.022 \\
\hline
\end{tabular}

concentrations in the water column at Barang Lompo and Gusung Tallang were similar However, the average phosphate concentration was 2 times higher at Gusung Tallang than at Barang Lompo 0.6 and $0.3 \mu \mathrm{M}$, respectively), indicating that the phosphate concentration is usually higher at Gusung Tallang. The average values of the water column ammonium concentrations at Gusung Tallang and Barang Lompo were quite similar (2.6 and $2.2 \mu \mathrm{M}$, respectively). At Langkai, the average water column ammonium and phosphate concentrations were much lower $(1.0$ and $0.1 \mu \mathrm{M}$, respectively) than at the other 2 locations.

Ammonium and phosphate concentrations in the pore water were much higher than in the water column. Pore water ammonium concentrations increased gradually with increasing depth at all locations (Fig. 2). This increase was most pronounced at Gusung Tallang. The average ammonium concentration in the pore water (to a depth of $12 \mathrm{~cm}$ ) was highest at Gusung Tallang (136 $\mu \mathrm{M}$; Table $1 \mathrm{~B}$ ). At Barang Lompo and Langkai the concentrations were 60 and $106 \mu \mathrm{M}$, respectively. The pore water phosphate concentrations showed a decrease in concentration with increasing sediment depth at Barang Lompo. At Gusung Tallang and Langkai, no gradients were observed. The average phosphate concentration in the pore water was lowest at Gusung Tallang $(0.92 \mu \mathrm{M}$, to a depth of $14 \mathrm{~cm})$. Barang Lompo and Langkai had approximately the same average concentration $(5.5$ and $5.4 \mu \mathrm{M}$, to a depth of 12 and $10 \mathrm{~cm}$, respectively).

Water column:pore water ratios were obtained by dividing the average water column concentrations by pore water concentrations averaged over the total core depth (Table $1 \mathrm{C}$ ). With respect to ammonium, the ratio

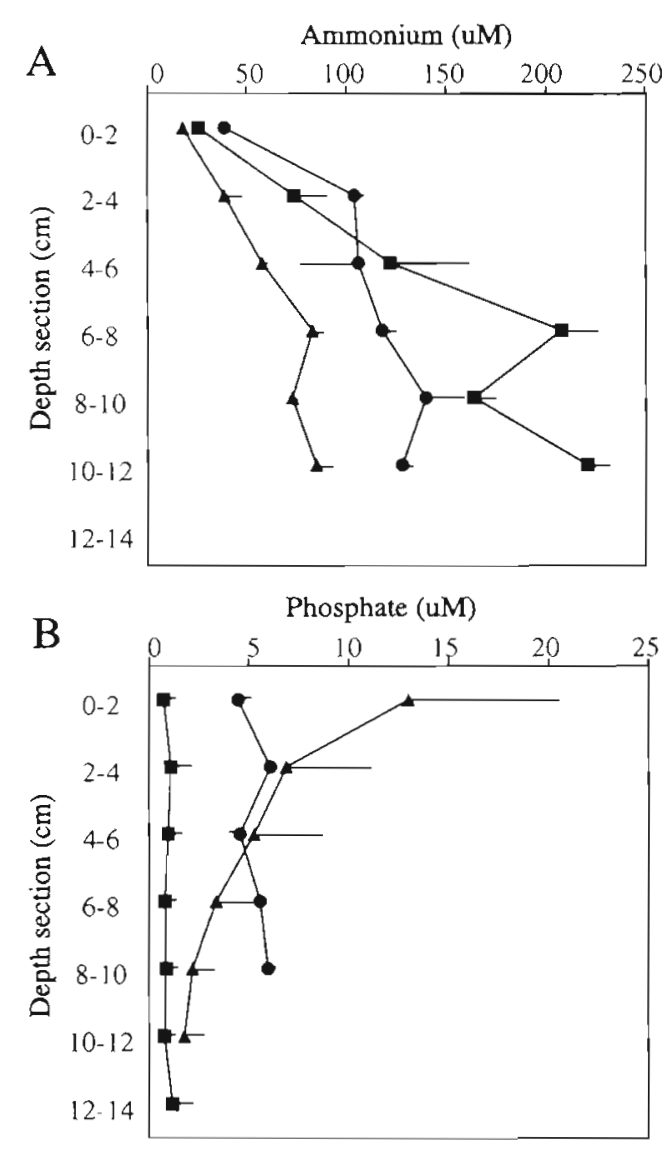

Fig. 2. Concentration ( $\mu \mathrm{M}$ ) of inorganic (A) ammonium and (B) phosphate in the pore water at Gusung Tallang (-), Barang Lompo (4) and Langkai (•) at different depth sections in the sediment. Bars represent $1 \mathrm{SD}$. For ammonium at all sites $\mathrm{n}=2$. For phosphate at Gusung Tallang $n=16$; at Barang Lompo $n=$ 31; at Langkaia $n=2$. 'Data supplied by Erftemeijer (1994) 
was highest (0.039) at Barang Lompo, indicating the relative importance of ammonium in the water column at this site, and lowest (0.0094) at Langkai. With regards to phosphate, the ratio was an order of magnitude higher at Gusung Tallang (0.64) than at Barang Lompo (0.051) and Langkai (0.022).

\section{Uptake kinetics of leaves}

Experiments with incubation vessels without plants (blanks) showed minimal fluctuations in medium ammonium and phosphate concentrations during incubations (the coefficient of variation of the various sets of values was around $5 \%$ ). Furthermore, there was no statistical evidence for a decrease or increase of the ammonium or phosphate concentration with time. Therefore, blank measurements were not taken into account in the calculations of kinetic parameters.

Ammonium and phosphate uptake kinetics of leaves of Thalassia hemprichii from 3 different locations are presented in Figs. 3 \& 4 . No difference was observed between curve profiles of uptake experiments from the same location but initiated at different concentrations or between curve profiles of experiments executed on different dates (different curves not shown), indicating that uptake was not influenced by feedback inhibition and that variation between experiments carried out at different dates was insignificant. Therefore, all data were combined for curve fitting according to the Michaelis-Menten equation. The resulting kinetic and statistical parameters are presented in Table 2 . The estimates of the model parameters $\left(V_{\max }\right.$ and $K_{\mathrm{m}}$ ) show no significant difference between the 3 locations. The lack of significance is mainly due to the larger error distribution at higher concentrations. At a low $\left(<K_{\mathrm{m}}\right)$ concentration range, the errors are much smaller. In this range, the 3 locations do not show a similar relationship between substrate and uptake rate. A good indication of the efficiency of nutrient uptake at low concentrations (the normal field situation) is the uptake affinity. Theoretically, the uptake affinity is given by $v_{\max } / K_{\mathrm{m}}$. Here, we approximated affinity by the initial slope of the $V$ versus $S$ curve (Button 1978, Riegman \& Mur 1984, Short \& McRoy 1984\}. This initial slope was determined by linear regression of the uptake rates at low nutrient concentrations. The regression analysis was carried out for the ammonium uptake data in the range of 0 to $20 \mu \mathrm{M}$ and for phosphate data in the range of 0 to $10 \mu \mathrm{M}$. Covariance analysis revealed that leaves from Langkai have a significantly $(p<$ 0.05 ) lower affinity for ammonium than leaves from Barang Lompo and Gusung Tallang. Leaves from
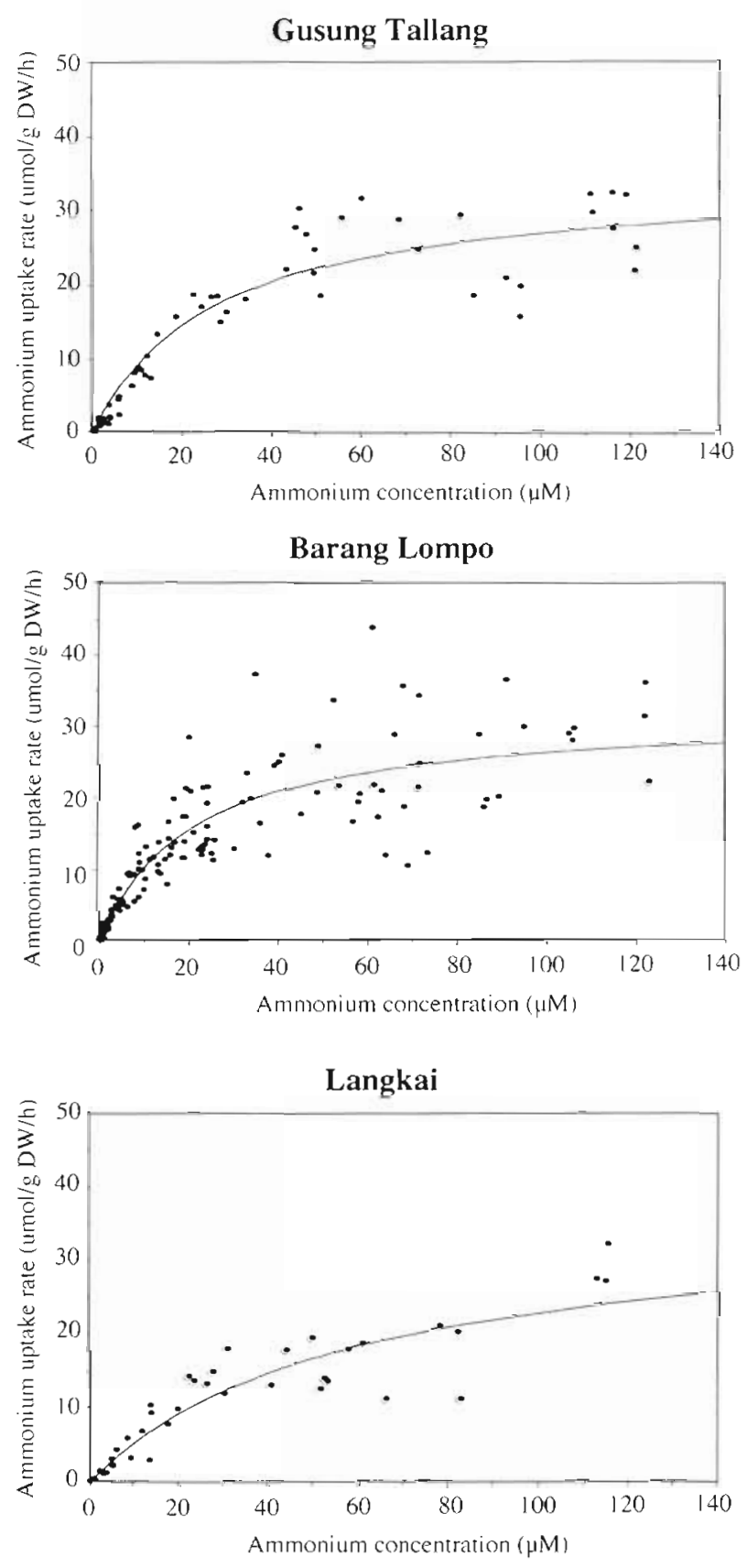

Fig. 3. Thalassia hemprichii. Ammonium uptake rate ( $\mu \mathrm{mol}$ $\mathrm{g}^{-1}$ dry weight $\mathrm{h}^{-1}$ ) by leaves of plants from Gusung Tallang, Barang Lompo and Langkai as a function of the ammonium concentration $(\mu \mathrm{M})$ in the leaf compartment. The curves represent the best fits according to the Michaelis-Menten model (see Table 2 and Material and methods: Uptake kinetics of leaves for explanation)

Gusung Tallang have a significantly $(p<0.05)$ higher affinity for phosphate than leaves from the other 2 locations. Linear regression to other data ranges revealed comparable results, if the upper concentration limit was not too high (a maximum of ca $K_{\mathrm{m}}$ ) and 
the data set included a substantial number of observations. The reported ranges revealed an acceptable $R^{2}$ and a significant regression coefficient $(p<0.01$; Table 2) for all 3 sites.
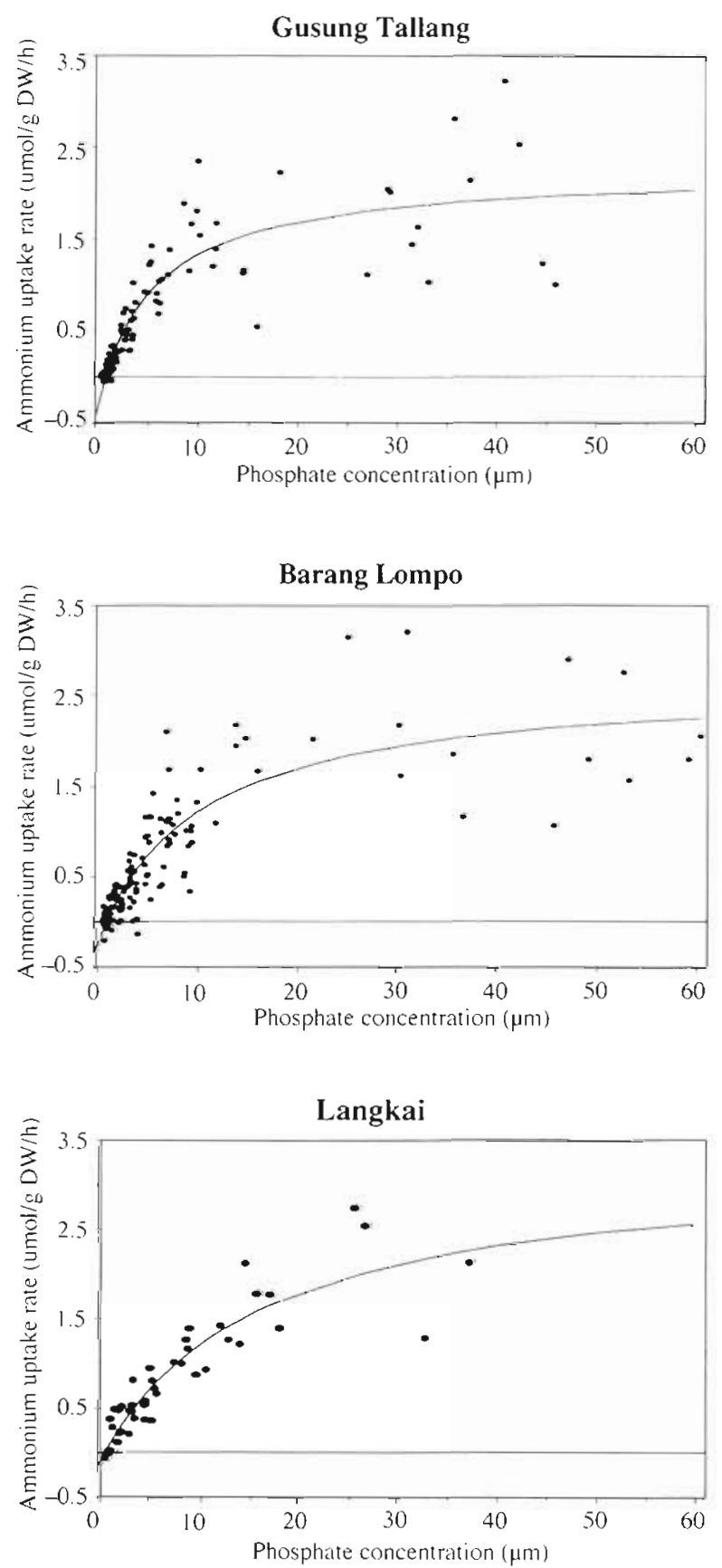

Fig. 4. Thalassia hemprichii. The phosphate uptake rate ( $\mu \mathrm{mol}$ $\mathrm{g}^{-1}$ dry weight $\mathrm{h}^{-1}$ ) by leaves of plants from Gusung Tallang, Barang Lompo and Langkai as a function of the phosphate concentration $(\mu \mathrm{M})$ in the leaf compartment. The curves represent the best fits according to the Michaelis-Menten model (see Table 2 and text for explanation)
In the case of phosphate uptake kinetics, the parameter representing the intercept on the $x$-axis $\left(S_{\text {Inin }}\right)$ was around $1 \mu \mathrm{M}$ phosphate at each location (Table 2). This is the ambient phosphate concentration above which net phosphate uptake by leaves occurs

\section{Uptake kinetics of roots}

Ammonium and phosphate taken up by the roots (expressed per gram dry weight) increased linearly with incubation time (Figs. $5 \& 6$ ). During the course of the incubation, no indication of substrate limitation could be detected. The ammonium concentration declined by $34 \%$, the phosphate concentration declined by $30 \%$. In the case of phosphate, the decrease of concentration in the medium during the first 10 to 15 min was probably influenced to an important degree by adsorption.

Table 2. Thalassia hemprichii. Uptake of ammonium and phosphate by leaves of plants from 3 different locations. $v_{\max }$ ( $\mu \mathrm{mol} \mathrm{g}^{-1}$ dry weight $\mathrm{h}^{-1}$ ) and $K_{\mathrm{M}}(\mu \mathrm{M})$ for the uptake of ammonium and phosphate and $S_{\min }$ (intercept on $x$-axis; in $\mu \mathrm{M}$ ) for the uptake of phosphate, with $95 \%$ confidence limits (CL: asymptotic SE) and $\mathrm{R}^{2}$ (Michaelis-Menten model). The affinity is given by the slope of the linear regression lines (affinity model) calculated for uptake at low nutrient concentrations $10-20 \mu \mathrm{M}$ for ammonium and $0-10 \mu \mathrm{M}$ for phosphate). The p-level of the regression coefficient and $R^{2}$ of the affinity model are included

\begin{tabular}{|c|c|c|c|}
\hline & Gusung Tallang & Barang Lompo & Langkai \\
\hline \multicolumn{4}{|c|}{ Ammonium } \\
\hline \multicolumn{4}{|c|}{ Michaelis-Menten model } \\
\hline$V_{\max }$ & 35 & 32 & 37 \\
\hline $95 \% \mathrm{CL}$ & $30-39$ & $28-35$ & $25-48$ \\
\hline$K_{M}$ & 28 & 21 & 60 \\
\hline $95 \% \mathrm{CL}$ & $19-38$ & $15-27$ & $14-97$ \\
\hline $\mathrm{R}^{2}$ & 0.888 & 0.829 & 0.866 \\
\hline \multicolumn{4}{|c|}{ Affinity model } \\
\hline affinity & 0.797 & 0.857 & 0.525 \\
\hline p-level & $<0.01$ & $<0.01$ & $<0.01$ \\
\hline $\mathrm{R}^{2}$ & 0.935 & 0.866 & 0.796 \\
\hline \multicolumn{4}{|c|}{ Phosphate } \\
\hline \multicolumn{4}{|c|}{ Michaelis-Menten model } \\
\hline$V_{\max }$ & 2.2 & 2.5 & 3.2 \\
\hline $95 \% \mathrm{CL}$ & $2.0-2.7$ & $2.2-2.8$ & $2.3-4.0$ \\
\hline$K_{M}$ & 7.7 & 11 & 15 \\
\hline $95 \% \mathrm{CL}$ & $5.2-10$ & $7.5-14$ & $7.9-23$ \\
\hline$S_{\min }$ & 0.91 & 1.1 & 0.71 \\
\hline $95 \%$ CL & $0.60-1.2$ & $0.76-1.5$ & $-0.24-1.7$ \\
\hline$R^{2}$ & 0.781 & 0.709 & 0.837 \\
\hline \multicolumn{4}{|c|}{ Affinity model } \\
\hline affinity & 0.190 & 0.131 & 0.125 \\
\hline p-level & $<0.01$ & $<0.01$ & $<0.01$ \\
\hline $\mathrm{R}^{2}$ & 0.869 & 0.612 & 0.778 \\
\hline
\end{tabular}




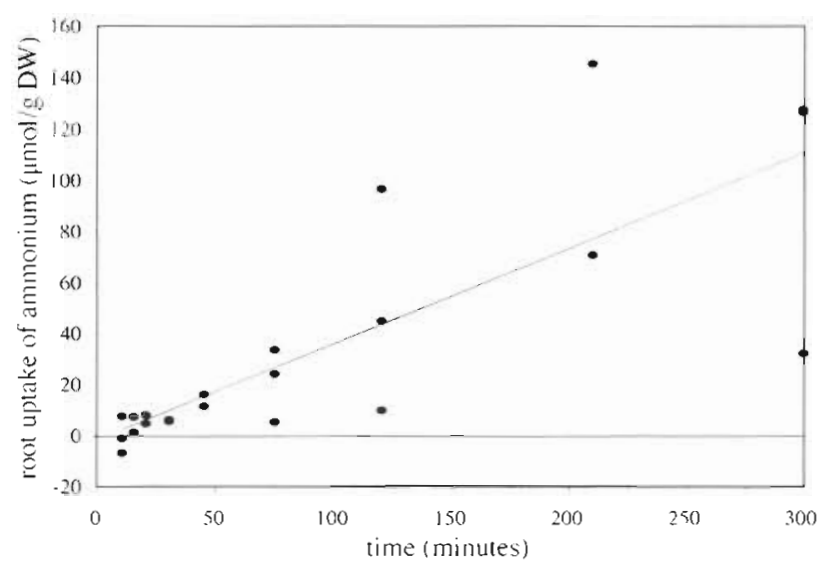

Fig. 5. Thalassia hemprichii. Ammonium uptake $\left(\mu \mathrm{mol} \mathrm{g}^{-1} \mathrm{dry}\right.$ weight) by roots of plants from Barang Lompo as a function of time. The initial ammonium concentrations were 18 and $54 \mu \mathrm{M}$ in the leaf and root compartments, respectively. The regression line shown is described by the formula $y=0.37 x+$ $b\left(p<0.01 ; R^{2}=0.650\right.$; see text for explanation $)$

The data were fitted by linear regression. From the regression lines, uptake rates of $22 \mathrm{~mol} \mathrm{~g}^{-1}$ dry weight $\mathrm{h}^{-1}$ and $1.0 \mu \mathrm{mol} \mathrm{g}{ }^{-1}$ dry weight $\mathrm{h}^{-1}$ can be derived for ammonium and phosphate, respectively. As the incubations were carried out at approximately natural nutrient concentration levels, these figures can be taken as an indication of uptake rates under natural conditions. The approach used did not allow determination of $v_{\max }, K_{\mathrm{m}}$ or affinity.

\section{DISCUSSION}

The results of this study show that leaves of the tropical seagrass Thalassia hemprichii have the ability to absorb ammonium and phosphate. This uptake capacity is remarkable in view of the low nutrient resources in the water column compared to the much higher resources in the pore water. Why does $T$. hemprichii possess this capacity? It suggests that roots lack the capacity to supply the total nutrient requirement. Maximum rates of nutrient uptake by roots are determined by the uptake capacity of the roots or by the rates of nutrient diffusion from pore water to the root surface. Which of these 2 processes is limiting can be determined by comparing the nutrient uptake of roots established in this study at in situ concentrations in stirred systems (Figs. $5 \& 6$ ) with the estimated diffusion supply of nutrients in the natural sediment conditions. Diffusion from the pore water to the root surface can be calculated with Fick's first law of diffusion: $J_{5}=-\phi \times D_{5} \times$ ( $\mathrm{d} S / \mathrm{d} x)$, where $J_{\mathrm{s}}$ is the nutrient flux in $\mu \mathrm{mol} \mathrm{cm}{ }^{-2} \mathrm{yr}^{-1}$, $\phi$ the porosity of the sediment, $D_{\mathrm{s}}$ the molecular diffu-

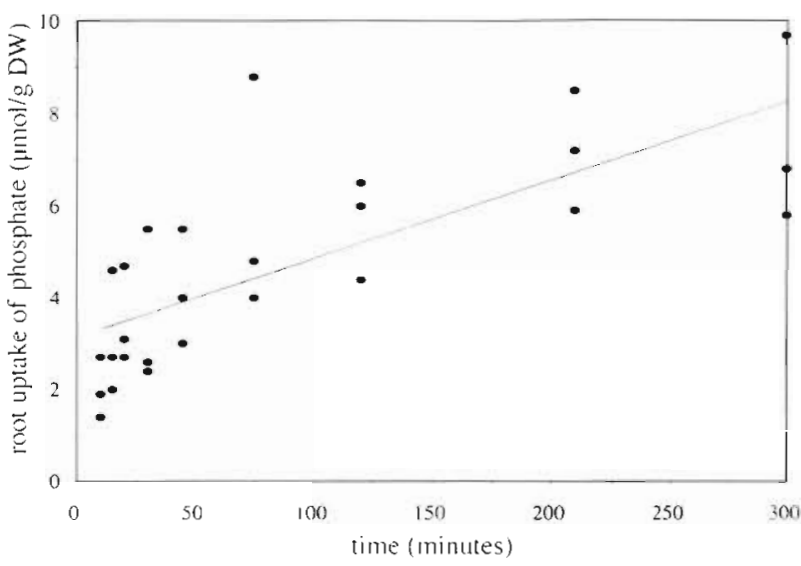

Fig. 6. Thalassia hemprichii. Phosphate uptake $\left(\mu \mathrm{mol} \mathrm{g}^{-1}\right.$ dry weight) by roots of plants from Barang Lompo as a function of time. The initial phosphate concentration was $6.5 \mu \mathrm{M}$ in both the leaf and root compartments. The regression line shown is described by the formula $y=0.017 x+b\left(p<0.01 ; R^{2}=0.484\right.$; see text for explanation)

sion coefficient in the sediment for the diffusing substance in $\mathrm{cm}^{2} \mathrm{yr}^{-1}$, and $\mathrm{d} S / \mathrm{d} x$ the concentration gradient over the diffusion layer $x$ in $\mu \mathrm{mol} \mathrm{cm}^{-3} \mathrm{~cm}^{-1} . D_{\mathrm{s}}$ and $\phi$ for Gusung Tallang and Barang Lompo are given by Erftemeijer \& Middelburg (1993). $D_{\mathrm{s}}$ and $\phi$ for Langkai are derived from data given by Erftemeijer (1994) and Erftemeijer \& Middelburg (1993). dS is the mean pore water concentration of ammonium and phosphate ('bulk concentration') given in Table 1B. The boundary (diffusion) layer thickness around roots ( $\mathrm{d} x$ ) is assumed to be approximately $1 \mathrm{~mm}$, a commonly accepted value for oxygen, phosphate and ammonium distribution around roots of various plants, including seagrasses (Andersen \& Kristensen 1988, Moriarty \& Boon 1989. Caffrey \& Kemp 1991, Jungk 1991, K. Buis, O. Van Tongeren \& T. Cappenberg unpubl.). The surface area of roots of $T$. hemprichii was established by measuring the diameter, length and biomass ( $g$ dry weight) of some individual roots. The diameter of the roots was approximately $0.5 \mathrm{~mm}$. This does not include the dense layer of root hairs covering the roots of $T$. hemprichii. Normally, root hairs are active in nutrient uptake for only a limited period. This means that active root hairs are in particular found close to the root tips, where recently formed root hairs are present. After deterioration, resistant cell wall structures, whose function is merely anchorage, remain (see reviews by Clarkson 1991 and Hofer 1991). We estimate that $1 \mathrm{~g}$ dry roots of $T$ hemprichii has a surface area of approximately $83 \mathrm{~cm}^{2}$. Using the various figures, diffusion of ammonium to the root surface at Barang Lompo for example equals, according to Fick's law, $0.53 \times 376.2 \times(60 \times$ $\left.10^{-3} / 0.1\right)=120 \mu \mathrm{mol} \mathrm{cm}{ }^{-2} \mathrm{yr}^{-1}$, which allows a maximal 
possible uptake of $120 \mu \mathrm{mol} \mathrm{cm}^{-2} \mathrm{yr}^{-1} \times 83 \mathrm{~cm}^{2} \mathrm{~g}^{-1}$ root dry weight. This is equivalent to an uptake of $1.1 \mu \mathrm{mol}$ $\mathrm{N}^{-1}$ root dry weight $\mathrm{h}^{-1}$. The maximum (diffusion) supply of nutrients to $T$. hemprichil roots at Barang Lompo can be compared with the uptake capacity of these roots as determined in the present incubation experiments. Diffusion may supply $1.1 \mu \mathrm{mol} \mathrm{N} \mathrm{g}^{-1}$ root dry weight $\mathrm{h}^{-1}$ and $0.041 \mu \mathrm{mol} \mathrm{P} \mathrm{g}^{-1}$ root dry weight $\mathrm{h}^{-1}$. This is 20 and 24 times less than the uptake capacity of the roots at natural pore water nutrient levels $(22$ and $1.0 \mu \mathrm{mol} \mathrm{g}^{-1}$ root dry weight $\mathrm{h}^{-1}$, for $\mathrm{N}$ and $\mathrm{P}$, respectively). The ammonium and phosphate uptake by roots therefore seems primarily dependent on diffusion limitations in the sediment and not on the uptake capacity of the roots. It is not impossible that the uptake capacity of roots as found in the experiments may have been below the normal in situ uptake capacity. Removal of sediment from the fragile roots, although executed with great care, undoubtedly caused damage to the roots and root hairs, resulting in a lower uptake capacity. Furthermore, during transport and incubation, the roots were exposed to environments with different oxygen levels, which may have disturbed their functioning.

If root uptake characteristics at Gusung Tallang and Langkai are approximately similar to those at Barang Lompo, it can be assumed that the diffusion supplies at Gusung Tallang and Langkai are probably less than the uptake capacity of roots. Nitrogen and phosphorus demand for leaf growth (which represent $95 \%$ of the plant nutrient demand; derived from Erftemeijer et al. 1993) can be estimated from leaf growth rates and leaf $\mathrm{N}$ and $\mathrm{P}$ contents. These figures are given for Thalassia hemprichii at Barang Lompo by Erftemeijer \& Herman (1994) (measurements of March. April,
May, June and July 1991, i.e. the months in which the uptake experiments were executed) and at Langkai by Stapel et al. (1996) (measured once in January 1994). For Gusung Tallang, no figures are available. Root uptake, as enabled by diffusion supply, is calculated with Fick's law using the average pore water nutrient concentrations from Table 1 In order to compare root uptake (which is calculated as nutrient diffusion to an equivalent of root biomass) with the plant's nutrient demand and uptake by leaves (which are expressed per gram of leaf biomass), the figures on diffusion supply to roots are divided by the ratio of leaf/root biomass (0.40 at Gusung Tallang and Barang Lompo and 0.36 at Langkai; Table 3). Except for the case of phosphate at Gusung Tallang (assuming that the phosphorus demand at this site is approximately similar to the demand at Barang Lompo and Langkai), roots alone seem to be able to meet total nitrogen and phosphorus demand, although the supply to these plant parts is limited by diffusion. It should be noted that the diffusion of nutrients to the surface area of rhizomes has been ignored in our calculations. It is known that rhizomes may absorb nutrients (Clarkson 1991). Barnabas (1991, 1994), however, showed that for 2 other tropical seagrass species, also occurring in the vicinity of our research area (Thalassodendron ciliatum and Halodule uninervis), the main function of the below ground plant parts is probably anchorage and uptake is limited to young, growing roots near the rhizome tip. If this is true for $T$. hemprichii as well, rhizome uptake may be insignificant and the active uptake surface may be even less than the root surface figure used for calculation of diffusion supply. Nutrient uptake by below ground plant parts may then be insufficient to meet total plant demand.

Table 3. Sediment parameters and Thalassia hemprichii root and leaf uptake and demand for nitrogen and phosphorus at Gusung Tallang (GT), Barang Lompo (BL) and Langkai (LK). Sediment parameters $\phi$ and $D_{\mathrm{s}}\left(\mathrm{cm}^{2} \mathrm{yr}^{-1}\right)$ derived from Erftemeijer (1994) and Erftemeijer \& Middelburg (1993). Root uptake ( $\mu \mathrm{mol} \mathrm{N}$ or $\mathrm{P}^{-1}$ leaf dry weight $\mathrm{h}^{-1}$ ) as determined by the maximum diffusion supply of nutrients to roots, calculated using Fick's first law of diffusion, divided by the leaf/root biomass ratio 10.4 at GT and BL; 0.36 at LK; see 'Discussion' for explanation). Leaf uptake ( $\mu$ mol $\mathrm{N}$ or $\mathrm{P}^{-1}$ leaf dry weight $\mathrm{h}^{-1}$ ) was calculated using the MichaelisMenten (M-M) model (Figs. 3 \& 4. Table 2) for the lowest (low), average (avg) and highest (high) natural water column concentrations (Table $1 \mathrm{~A}$ ). Demand ( $\mu \mathrm{mol} \mathrm{N}$ or $\mathrm{P}^{-1}$ leaf dry weight $\mathrm{h}^{-1}$ ) derived from data given by Erftemeijer \& Herman (1994) (BL) and Stapel et al. (unpubl.) (LK). Values \pm SD; nd: value not determined; $n$ : number of observations; df: degrees of freedom

\begin{tabular}{|c|c|c|c|c|c|c|c|}
\hline \multirow[t]{2}{*}{ Site } & \multicolumn{2}{|c|}{ Sediment parameters } & \multirow{2}{*}{$\begin{array}{l}\text { Root uptake } \\
\text { (diffusion) }\end{array}$} & \multicolumn{3}{|c|}{ Leaf uptake (M-M) } & \multirow[t]{2}{*}{ Demand } \\
\hline & $\phi(n=4)$ & $D_{\mathrm{s}}$ & & Low & $A v g$ & High & \\
\hline \multicolumn{8}{|c|}{ Ammonium } \\
\hline GT & $0.72 \pm 0.02$ & 397.6 & $9.2 \pm 0.54(\mathrm{df}=1)$ & 0.70 & 2.9 & 5.6 & nd \\
\hline $\mathrm{BL}$ & $0.53 \pm 0.04$ & 376.2 & $2.8 \pm 0.52(\mathrm{df}=1)$ & 1.2 & 3.0 & 6.4 & $2.3 \pm 0.8(\mathrm{df}=35)$ \\
\hline LK & 0.54 & 376.2 & 5.7 & 0.12 & 0.61 & 0.98 & $1.6 \pm 0.3(\mathrm{df}=2)$ \\
\hline \multicolumn{8}{|c|}{ Phosphate } \\
\hline $\mathrm{GT}$ & $0.72 \pm 0.02$ & 160.6 & $0.03 \pm 0.01(\mathrm{df}=15)$ & -0.20 & -0.10 & +0.052 & nd \\
\hline $\mathrm{BL}$ & $0.53 \pm 0.04$ & 152.0 & $0.10 \pm 0.05(\mathrm{df}=30)$ & -0.28 & -0.20 & +0.022 & $0.075 \pm 0.019(\mathrm{df}=44)$ \\
\hline LK & 0.54 & 152.0 & 0.12 & -0.16 & -0.14 & -0.11 & $0.047 \pm 0.010(\mathrm{df}=5)$ \\
\hline
\end{tabular}


Leaf uptake is dependent on the concentration in the water layer and diffusion across the boundary layer around the leaves. Assuming that diffusion limitation is negligible due to continuous turbulent water movement, leaves can absorb nutrients from the ambient water at a rate ( $V$ ) given by the uptake curves presented in Figs. 3 \& 4 . During the periods in which the leaf uptake experiments were executed, the water column nutrient concentrations showed considerable fluctuations. There are no indications that the uptake kinetics fluctuate accordingly. Using the data on the range and average ammonium and phosphate concentrations found in the field (Table 1A), the range of leaf uptake rates under natural conditions can be calculated for the 3 locations (Table 3 ). At the low end of the concentration range at Barang Lompo, leaf uptake of ammonium is insufficient to meet total demand (Table 3). At average concentrations, however, the uptake of leaves is sufficient. This is probably also true for plants at Gusung Tallang, assuming that the nitrogen demand at this site is approximately similar to the demand at Barang Lompo and Langkai. At Langkai, leaves do not seem to be able to meet the total nitrogen demand. Calculated phosphate uptake by leaves at natural water column concentrations was always negative at Langkai and ranged from negative to positive values at Gusung Tallang and Barang Lompo. The negative values reflect the fact that the curves describing the relation between phosphate concentration and uptake rate have a positive intercept on the $x$-axis. Release of phosphate by leaves of seagrasses has been reported in earlier studies; it has been suggested that seagrasses may function as phosphorus pumps, relocating phosphorus from the sediment to the water column (McRoy \& Barsdate 1970, McRoy et al. 1972. McRoy \& Goering 1974. Carignan \& Kalff 1982). Studies of Penhale \& Thayer (1980) and PérezLloréns et al. (1993), however, indicate that this process is quantitatively insignificant. It should be realized that the negative uptake (release) of phosphate in our data result from a mathematical adaptation of the Michaelis-Menten curve. It may well be that physiological mechanisms in the plant prevent release at very low concentrations. However, our results indicate that net phosphate uptake only occurs in situations when the phosphate concentration in the water column is above a certain level, i.e. at a concentration higher than $S_{\min }$ (Table 2). This situation frequently occurs in the period between June and December at Gusung Tallang and Barang Lompo (Erftemeijer \& Herman 1994). During this period, Thalassia hemprichii might take advantage of the capability of the leaves to take up phosphate. This could be especially important at Gusung Tallang, as the calculated diffusion supply of phosphate to the roots at this site is much lower than at Barang Lompo or Langkai. Data on seasonal variation of inorganic phosphate are not available for Langkai. Available data from 3 sampling dates (once in September 1990 and twice in January 1994) show phosphate levels below $S_{\mathrm{m} n \mathrm{n}}$. It is indeed possible that at this oceanic site, the phosphate concentration never or only seldom reaches levels high enough for net phosphate uptake by leaves. Nonetheless, uptake experiments demonstrate that $T$. hemprichii leaves do possess a clear potential for phosphate uptake at Langkai. The relevance of this property at Langkai is not clear.

The uptake affinities of leaves (Table 2) showed some differences between the 3 locations. The uptake affinity for phosphate was significantly higher at Gusung Tallang compared to the other locations. At Langkai, the affinity for ammonium was significantly lower than at Gusung Tallang and Barang Lompo. Erftemeijer et al. (1994), using in situ addition of both nitrogen and phosphorus fertilizers to the root zone of carbonate and terrigenous type seagrass beds in the same research area (Barang Lompo, another coral island and a terrigenous site comparable to Gusung Tallang), could not demonstrate growth Iimitation by either of the 2 nutrients. Comparison of leaf nitrogen and phosphorus content revealed no significant differences between the locations (Erftemeijer 1993, Erftemeijer \& Herman 1994, Erftemeijer et al. 1994, Stapel et al. 1996). The differences in uptake affinities of the leaves may be related to the leaf zone:root zone nutrient concentration ratios (Table $1 \mathrm{C}$ ), which showed some differences among the 3 locations. The ammonium concentration ratio was lowest at Langkai and highest at Barang Lompo (Table 1C). At Gusung Tallang, the phosphate ratio was an order of magnitude higher than at Barang Lompo and Langkai. Comparison with the uptake affinities of leaves show that a higher concentration ratio corresponds with a higher leaf uptake affinity. The data thus suggest that there is some form of physiological integration between leaves and roots with respect to nutrient uptake, leading to the adaptation of uptake properties depending on available resources. The plants may optimize their leaf uptake capacity according to the relative nutrient availability in the water column and the pore water. Interaction between leaf and root uptake in relation to different concentration ratios was previously reported by Thursby \& Harlin (1982, 1984) for Zostera marina and Ruppia maritima. In short-term experiments $(5 \mathrm{~h})$ with Thalassia hemprichii, such interactions could not be demonstrated (Stapel et al. unpubl.). Physiological interaction of leaf and root uptake characteristics in $T$. hemprichii may occur on more extended time scales. 
Acknowledgements. Drs P. H. Nienhuis, J. J. Middelburg and J. C. Kromkamp are acknowledged for their critical comments on earlier drafts of this manuscript. Sahid, Buang, lbrahim, Bas Philipsen, Rebi Nijboer and Mark Erdmann provided field assistance. Statistical advice was provided by Dr P. M. J. Herman. The equipment used was kindly prepared by Ko Hoekman, Lowic Haazen and Chris Almekinders. This study was funded by the Netherlands Foundation for the Advancement of Tropical Research (WOTRO; grant W86-108). Communication no. 2126 of the Netherlands Institute of Ecology, Centre for Estuarine and Coastal Ecology, Yerseke, The Netherlands

\section{LITERATURE CITED}

Andersen FØ, Kristensen E (1988) Oxygen microgradients in the rhizosphere of the mangrove Avicenna marina. Mar Ecol Prog Ser 44:201-204

Barnabas AD (1991) Thalassodendron ciliatum (Forssk.) Den Hartog: root structure and histochemistry in relation to apoplastic transport. Aquat Bot 40:129-143

Barnabas AD (1994) Apoplastic and symplastic pathways in leaves and roots of the seagrass Halodula uninervis (Forssk.) Aschers. Aquat Bot 47:155-174

Berges JA, Montagnes DJS, Hurd CL, Harrison PJ (1994) Fitting ecological and physiological data to rectangular hyperbolae: a comparison of methods using Monte Carlo simulations. Mar Ecol Prog Ser 144:175-183

Brouns JJWM, Heijs FML (1986) Production and biomass of the seagrass Enhalus acoroides (L.f.) royle and its epiphytes. Aquat Bot 25:21-45

Button DK (1978) On the theory of control of microbial growth kinetics by limiting nutrient concentratıons. Deep Sea Res 25:1163-1177

Caffrey JM, Kemp WM (1991) Seasonal and spacial patterns of oxygen production, respiration and root-rhizome release in Potamogeton perfoliatus L. and Zostera marina $\mathrm{L}$ Aquat Bot 40:109-128

Carignan R, Kalff J (1980) Phosphorus sources for aquatic weeds: water or sediments? Science 207:987-988

Carignan R, Kalff J (1982) Phosphate release by submerged macrophytes: significance to epiphyton and phytoplankton. Limnol Oceanogr 27(3):419-427

Clarkson DT (1991) Root structure and sites of ion uptake. In Waisel Y, Eshel A, Kafkafi U (eds) Plant roots: the hidden half. Marcel Dekker, Inc., New York, p 417-453

De Klerk LG (1982) Sea levels, reefs and coastal plains of southwest Sulawesi, Indonesia; a morphogenetic-pedological study. PhD thesis, State University of Utrecht (in Dutch)

Den Hartog C (1970) The seagrasses of the world. North Holland, Amsterdam

Doddema H, Howari M (1983) In vivo nitrate reductase activity in the seagrass Halophila stipulacea from the Gulf of Aqaba (Jordan). Bot Mar 26:307-312

Erftemeijer PLA (1993) Factors limiting growth and reproduction of tropical seagrasses: nutrient dynamics in Indonesian seagrass beds. PhD thesis, Catholic University of Nijmegen

Erftemeijer PLA (1994) Differences in nutrient concentrations and resources between seagrass communities on carbonate and terrigenous sediments in South Sulawesi, Indonesia. Bull Mar Sci 54(2):403-419

Erftemeijer PLA, Middelburg JJ (1993) Sediment-nutrient interactions in tropical seagrass beds: a comparison between a terrigenous and a carbonate sedimentary envi- ronment in South Sulawesi (Indonesia). Mar Ecol Prog Ser 102:187-198

Erftemeijer PLA, Herman PMJ (1994) Seasonal changes in environmental variables, biomass, production and nutrient contents in two contrasting tropical intertidal seagrass beds in South Sulawesi, Indonesia. Oecologia 99:45-59

Erftemeijer PLA, Osinga R, Mars A (1993) Primary production in seagrass beds in South Sulawesi (Indonesia): a comparison of habitats, methods and species. Aquat Bot 46:67-90

Erftemeijer PLA, Stapel J, Smekens MJE, Drossaert WME (1994) The limited effect of in situ phosphorus and nitrogen additions to seagrass beds on carbonate and terngenous sediments in South Sulawesı, Indonesia. J Exp Mar Biol Ecol 182:123-140

Hemminga MA, Harrison PG, Van Lent $F(1991)$ The balance of nutrient losses and gains in seagrass meadows. Mar Ecol Prog Ser 71:85-96

Hemminga MA, Koutstaal BP, Van Soelen J, Merks AGAM (1994) The nitrogen supply to intertidal eelgrass (Zostera marina L.). Mar Biol 118:223-227

Hillman K, Walker DI Larkum AWD, McComb AJM (1989) Productivity and nutrient limitation. In: Larkum AWD. McComb AJ, Shepherd SA (eds) Biology of seagrasses. A treatise on the biology of seagrasses with special reference to the Australian region. Aquatic plant studies 2 . Elsevier, Amsterdam, p 635-685

Hofer RM (1991) Root hairs. In: Waisel Y, Eshel A, Kafkafi U (eds) Plant roots: the hidden half. Marcel Dekker, Inc, New York, p 129-148

lizumi H. Hattori A (1982) Growth and organic production of eelgrass (Zostera marina L.) in temperate waters of the Pacific coast of Japan. III. The kinetics of nitrogen uptake. Aquat Bot 245-256

Jungk AO (1991) Dynamics of nutrient movement at the soilroot interface. In: Waisel Y, Eshel A, Kafkafi U (eds) Plant roots: the hidden half. Marcel Dekker, Inc., New York, $p$ $455-481$

Kelderman P (1985) Nutrient dynamics in the sediment of Lake Grevelingen (SW Netherlands). PhD thesis, State University of Groningen

Larkum AWD, West RJ (1983) Stability, depletion and restoration of seagrass beds. Proc Linn Soc NSW 106:201-212

Lindeboom HJ, Sandee AJJ (1989) Production and consumption of tropical seagrass fields in eastern Indonesia measured with bell jars and microelectrodes. Neth J Sea Res 23:181-190

McRoy CP, Barsdate RJ (1970) Phosphate absorption in eelgrass. Limnol Oceanogr 15:6-13

McRoy CP, Goering JJ (1974) Nutrient transfer between the seagrass Zostera marina and its epiphytes. Nature 248 $173-174$

McRoy CP, Barsdate RJ, Nebert M (1972) Phosphate cycling in an eelgrass (Zostera marina L.) ecosystem. Limnol Oceanogr $17(1): 58-67$

Moriarty DJW, Boon PI (1989) Interaction of seagrasses with sediment and water. In: Larkum AWD, McComb AJ, Shepherd SA (eds) Biology of seagrasses. A treatise on the biology of seagrasses with special reference to the Australian region. Aquatic plant studies 2. Elsevier, Amsterdam, p $500-535$

Nienhuis PH, Coosen J, Kiswara W (1989) Community structure and biomass distribution of seagrasses and macrofauna in the Flores Sea, Indonesia. Neth J Sea Res 23 $197-214$

Nissen P (1991) Uptake mechanisms. In: Waisel Y, Eshel A Kafkafi U (eds) Plant roots: the hidden half. Marcel Dekker. Inc, New York, p 417-453 
Pedersen MF, Borum J (1992) Nitrogen dynamics of eelgrass Zostera marına during a late summer period of high growth and low nutrient availability. Mar Ecol Prog Ser 80: 65-73

Pedersen MF, Borum J (1993) An annual nitrogen budget for a seagrass Zostera marina population. Mar Ecol Prog Ser 101:169-177

Penhale PA, Thayer GW (1980) Uptake and transfer of carbon and phosphorus by eelgrass (Zostera marina L.) and its epiphytes. J Exp Mar Biol Ecol 42:113-123

Pérez-Lloréns JL, De Visser P, Nienhuis PH, Niell FX (1993) Light-dependent uptake, translocation and foliar release of phosphorus by the intertidal seagrass Zostera noltii Hornem. J Exp Mar Biol Ecol 166:165-174

Riegman R, Mur LR (1984) Regulation of phosphate uptake kinetics in Oscillatoria agardhii. Arch Microbiol 139:28-32

Short FT, McRoy CP (1984) Nitrogen uptake by leaves and roots of the seagrass Zostera marina L. and its epiphytes. Bot Mar 27:547-555

Smith FA, Walker NA (1980) Photosynthesis by aquatic plants: effects of unstirred layers in relation to assimilation of $\mathrm{CO}_{2}$ and $\mathrm{HCO}_{3}{ }^{-}$and to carbon isotopic discrimination. New Phytol 86:245-259

This article was submitted to the editor
Stapel J, Nijboer R, Philipsen B (1996) Initial estimates of the export of leaf litter from a seagrass bed in the Spermonde Archipelago, South Sulawesi, Indonesia. In: Kuo J, Phillips RC, Walker DI, Kirkman H (eds) Seagrass biology: proceedings of an international workshop. Faculty of Sciences, The University of Western Australia, Nedlands, p $155-162$

Sterrenburg FAS, Erftemeijer PLA, Nienhuis PH (1995) Diatoms as epiphytes on seagrass in South Sulawesi. (Indonesia). Comparison with growth on inert substrata. Bot Mar 38:1-7

Strickland JDH, Parsons TR (1972) A practical handbook of seawater analysis. Bull Fish Res Bd Can 167:1-311

Thursby GB, Harlin MM (1982) Leaf-root interaction in the uptake of ammonia by Zostera marina. Mar Biol 72: $109-112$

Thursby GB, Harlin MM (1984) Interaction of leaves and roots of Ruppia maritima in the uptake of phosphate, ammonia and nitrate. Mar Biol 83:61-67

Zieman JC, Wetzel RG (1980) Productivity in seagrasses: methods and rates. In: Phillips RC, McRoy CP (eds) Handbook of seagrass biology: an ecosystem perspective. Garland STMP Press, New York, p 87-116

Manuscript first recelved: June 12, 1995

Revised version accepted: October 25, 1995 